\title{
Thermodynamic examination of trinucleotide bulged RNA in the context of HIV-1 TAR RNA
}

\author{
IAN CARTER-O'CONNELL, ${ }^{1}$ DAVID BOOTH, ${ }^{2}$ BRYAN EASON, ${ }^{3}$ and NEENA GROVER \\ Department of Chemistry and Biochemistry, The Colorado College, Colorado Springs, Colorado 80903, USA
}

\begin{abstract}
RNA structures contain many bulges and loops that are expected to be sites for inter- and intra-molecular interactions. Nucleotides in the bulge are expected to influence the structure and recognition of RNA. The same stability is assigned to all trinucleotide bulged RNA in the current secondary structure prediction models. In this study thermal denaturation experiments were performed on four trinucleotide bulged RNA, in the context of HIV-1 TAR RNA, to determine whether the bulge sequence affects RNA stability and its divalent ion interactions. Cytosine-rich bulged RNA were more stable than uracil-rich bulged RNA in $1 \mathrm{M} \mathrm{KCl}$. Interactions of divalent ions were more favorable with uracil-rich bulged RNA by $\sim 2 \mathrm{kcal} / \mathrm{mol}$ over cytosine-rich bulged RNA. The UCU-TAR RNA (wild type) is stabilized by $1.7 \mathrm{kcal} / \mathrm{mol}$ in $9.5 \mathrm{mM} \mathrm{Ca}{ }^{2+}$ as compared with $1 \mathrm{M} \mathrm{KCl}$, whereas no additional gain in stability is measured for CCC-TAR RNA. These results have implications for base substitution experiments traditionally employed to identify metal ion binding sites. To our knowledge, this is the first systematic study to quantify the effect of small sequence changes on RNA stability upon interactions with divalent ions.
\end{abstract}

Keywords: RNA thermodynamics; metal-RNA interactions; divalent ion interactions with bulged RNA; bulge stabilities

\section{INTRODUCTION}

RNA structures are made up of helical regions that are interspersed with a large number of nonhelical regions, such as loops and bulges, which are crucial for creating the diversity seen in the three-dimensional structures of RNA (Turner 1992; Hermann and Patel 2000). Bulges are one of the most common nonhelical structural features in RNA and the size of the bulge varies from one to several nucleotides. In an asymmetric bulge, additional nucleotides on one strand have no partner on the corresponding strand. The unpaired nucleotides of the bulge can either be stacked in the helix or looped out, causing them to be stacked or unstacked outside the helix. Bulges are often sites for intramolecular interactions and intermolecular recognition; bulge nucleotides can serve as recognition sites

Present addresses: ${ }^{1}$ Department of Molecular and Cellular Biology, Harvard University, Cambridge, MA 02138, USA; ${ }^{2}$ Graduate Group in Biophysics, University of San Francisco, CA 94158, USA; ${ }^{3}$ Center for Veterinary Sciences, Oklahoma State University, Stillwater, OK 74078, USA.

Reprint requests to: Neena Grover, Department of Chemistry and Biochemistry, 14 E. Cache La Poudre Street, Colorado College, Colorado Springs, CO 80903, USA; email: ngrover@coloradocollege.edu; fax: (719) 389-6182.

Article published online ahead of print. Article and publication date are at http://www.rnajournal.org/cgi/doi/10.1261/rna.1004108. for sequence-specific interactions and their presence distorts the surrounding helices, creating additional features for specific recognition by target molecules (White and Draper 1987; Wu and Uhlenbeck 1987; Roy et al. 1990; Zacharias and Hagerman 1995b; Hermann and Patel 2000). Bulge nucleotides are being introduced into antisense RNA for various applications, including targeted chemical cleavage of RNA (Huesken et al. 1996; Madder et al. 2003).

Asymmetric bulge regions are expected to be sites for interactions with positively charged ions, thus neutralizing the charges on phosphates that are in close proximity due to distortion of the RNA backbone (Hermann and Patel 2000). Metal ion binding sites are often identified by RNA crystallography when crystals are grown in high concentrations of monovalent and divalent ions (Cate and Doudna 1996; Correll et al. 1997; Basu et al. 1998). Biophysical studies provide additional data on sites of interaction and binding constants for metal-RNA interactions (Aboul-ela et al. 1995; Zacharias and Hagerman 1995a; Edwards and Sigurdsson 2003; Casiano-Negroni et al. 2007). However, the extent to which divalent ions stabilize RNA structures, including bulges, is not known.

TAR RNA is a hairpin formed between position +1 and +59 (approximately) of HIV-1 RNA (Coffin et al. 1997; Frankel and Young 1998) and contains a UCU bulge. The bulge region interacts with the Tat protein, in complex with 
cyclin $\mathrm{T} 1$, to increase the rate of transcription by nearly 100-fold (Coffin et al. 1997; Frankel and Young 1998). Hence, TAR RNA has been extensively studied by biochemical and biophysical methods (Muesing et al. 1987; Dingwall et al. 1989; Cordingley et al. 1990; Weeks et al. 1990; Calnan et al. 1991; Puglisi et al. 1992; Tao and Frankel 1992; Aboul-ela et al. 1995, 1996; Zacharias and Hagerman 1995a; Ippolito and Steitz 1998; Edwards and Sigurdsson 2003; Casiano-Negroni et al. 2007). The trinucleotide (UCU) bulge is at position 23-25 (HIV-1 TAR RNA numbering system is being used here) (Fig. 1A); the two adjoining base pairs on each of the upper and lower helical stem are conserved (Fig. 1A, shown in italics). The crystal structure of HIV-1 TAR RNA shows four $\mathrm{Ca}^{2+}$ binding sites that stabilize an alternate conformation of TAR RNA that is not expected to bind to Tat protein (Ippolito and Steitz 1998). Transient electric birefringence experiments on TAR RNA show that $\mathrm{Mg}^{2+}$ ions straighten the bend in TAR RNA by nearly $50 \%$ and do not interfere with the binding of arginine (Zacharias and Hagerman 1995a). Residual dipolar coupling NMR experiments show that binding of arginine changes the interhelical angle and arrests interhelical motion; $\mathrm{Na}^{+}$and $\mathrm{Mg}^{2+}$ stabilize TAR RNA by different modes of interactions (Pitt et al. 2004; Casiano-Negroni et al. 2007). In EPR studies, $\mathrm{Na}^{+}$and $\mathrm{Ca}^{2+}$ caused similar changes in mobility, while $\mathrm{Mg}^{2+}$ affected RNA differently at one of the bulge positions (Edwards and Sigurdsson 2003). Two bulge residues are expected to be part of the "hinge" region for RNA motions in TAR RNA (Musselman et al. 2007). Thus, TAR RNA is an ideal candidate to study the role of bulge nucleotides in RNA stability and to quantify the magnitude of RNA-metal interactions.

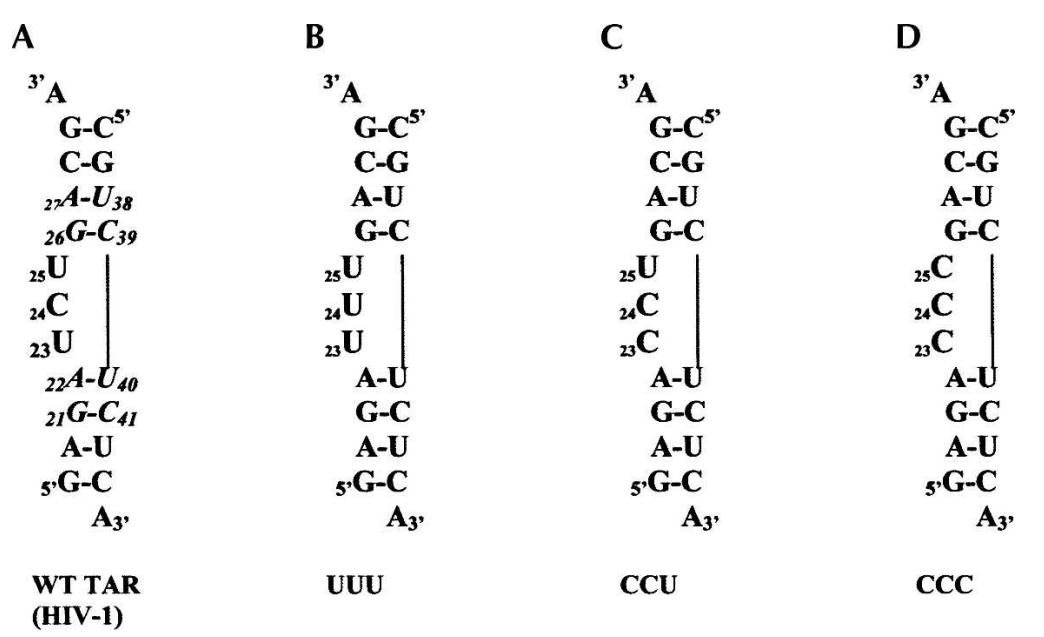

FIGURE 1. TAR RNA construct and modifications used in this study. (A) Wild-type TAR RNA construct from HIV-1 containing the UCU bulge at positions 23-25 and the conserved base pairs A27-C38, C26-C39, A22-U40, and G21-C41 are shown in italics; (B) UUU-TAR, where $\mathrm{C} 24$ has been changed to U24; $(C)$ CCU-TAR, where U23 changed to C23; and $(D)$ CCC-TAR, where U23 and U25 have been changed to cytosine.

\section{RESULTS}

\section{RNA with the UCU bulge is the least stable in $1 \mathrm{M}$ salt}

The thermodynamic properties of four trinucleotidebulged RNAs, with pyrimidine nucleotides in the bulge of HIV-1 TAR RNA (Fig. 1), and a core helix, were measured in a buffer containing $1 \mathrm{M} \mathrm{KCl}$. The UCU-TAR RNA is 1.2 $\mathrm{kcal} / \mathrm{mol}$ less stable than CCC-TAR RNA (Table 1). The stability of CCU-TAR and UUU-TAR RNA is identical and in-between the stability of UCU-TAR and CCC-TAR RNA. The core helix was significantly destabilized by the interruption caused by the bulge (Table 1 ).

\section{TAR RNA is stabilized by a low concentration of calcium ions}

Thermal denaturation experiments were performed on the wild-type TAR RNA construct (UCU-TAR RNA) in buffers containing varying concentrations of calcium, magnesium, and barium ions (Table 2) following the protocols presented in the Materials and Methods section. As expected, UCU-TAR RNA is relatively unstable in a $10 \mathrm{mM} \mathrm{KCl}$ buffer, with a $\Delta \mathrm{G}^{\circ}{ }_{37}$ value of $-3.8 \mathrm{kcal} / \mathrm{mol}$. Addition of just $0.5 \mathrm{mM} \mathrm{Ca}^{2+}$ increases RNA stability by an additional $4 \mathrm{kcal} / \mathrm{mol}$ (Fig. 2A, filled diamonds); a further increase in calcium concentration, up to $9.5 \mathrm{mM}$, added $0.9 \mathrm{kcal} / \mathrm{mol}$ to RNA stability. In low concentrations of divalent ions (0-4 mM range), $\mathrm{Ca}^{2+}$ stabilizes UCU-TAR RNA more than $\mathrm{Mg}^{2+}$. As the concentration of metal ions is increased ( $>5 \mathrm{mM}$ ), the stability of TAR RNA in $\mathrm{Ca}^{2+}$ and $\mathrm{Mg}^{2+}$ is within $1 \mathrm{kcal} / \mathrm{mol}$ (Fig. 2, cf. A and B). Interactions of UCU-TAR RNA with $\mathrm{Ba}^{2+}$ ions were similar to those with $\mathrm{Ca}^{2+}$ (Table 2).

A few metal titration experiments were also performed in a high-salt buffer (Table 3). Even under these conditions, UCU-TAR RNA was 0.4 $\mathrm{kcal} / \mathrm{mol}$ more stable in $0.5 \mathrm{mM} \mathrm{Ca}^{2+}$ and $1.5 \mathrm{kcal} / \mathrm{mol}$ more stable in $9.5 \mathrm{mM}$ $\mathrm{Ca}^{2+}$ as compared with $1 \mathrm{M} \mathrm{K}^{+}$(and $9.5 \mathrm{mM} \mathrm{Mg}^{2+}$ ). Thus, high concentrations of monovalent ions competed more effectively with $\mathrm{Mg}^{2+}$ interactions with UCU-TAR RNA than with $\mathrm{Ca}^{2+}$ interactions.

\section{Thermodynamic properties of modified bulge nucleotides and the core helix}

Table 4 shows the thermodynamic parameters for CCU-TAR RNA, UUUTAR RNA, CCC-TAR RNA, and the core helix in various concentrations of divalent ions. A small change in the 
TABLE 1. Themodynamic parameters of UCU-TAR, UUU-TAR, CCU-TAR, and CCC-TAR RNA in $1 \mathrm{M}$ salt

\begin{tabular}{lcccc}
\hline $\begin{array}{l}\text { Bulge } \\
\text { sequence }\end{array}$ & $\begin{array}{c}\Delta \mathrm{H}^{\circ} \\
(\mathrm{kcal} / \mathrm{mol})\end{array}$ & $\begin{array}{c}\Delta \mathrm{S}^{\circ} \\
(\mathrm{eu})\end{array}$ & $\begin{array}{c}\Delta \mathrm{G}^{\circ} \\
\left(\mathrm{kcal} / \mathrm{mol}, 37^{\circ} \mathrm{C}\right)\end{array}$ & $\begin{array}{c}T_{m} \\
\left({ }^{\circ} \mathrm{C}, 1.0 \mathrm{e}-04 \mathrm{M}\right)\end{array}$ \\
\hline UCU & $-54 \pm 4$ & $-150 \pm 12$ & $-7.2 \pm 0.1$ & 40.8 \\
CCU & $-53 \pm 6$ & $-146 \pm 20$ & $-7.9 \pm 0.3$ & 45.1 \\
UUU & $-73 \pm 4$ & $-210 \pm 12$ & $-7.9 \pm 0.1$ & 43.0 \\
CCC & $-55 \pm 4$ & $-149 \pm 13$ & $-8.4 \pm 0.1$ & 47.7 \\
Helix & $-99 \pm 3$ & $-266 \pm 7$ & $-16.5 \pm 0.2$ & 71.8 \\
\hline
\end{tabular}

most favorable $\left(\Delta \Delta \mathrm{G}^{\circ}{ }_{37}\right.$ of $1.8 \mathrm{kcal} /$ $\mathrm{mol})$. This is $\sim 0.8 \mathrm{kcal} / \mathrm{mol}$ more favorable than the other bulged RNA sequences (Fig. 3B, green bars). The core helix is maximally stabilized in $1 \mathrm{M} \mathrm{KCl}$; interactions with $\mathrm{Mg}^{2+}$ and $\mathrm{Ca}^{2+}$ ions do not increase core helix stability (Fig. 3A,B). Cytosine-rich bulged RNA behaved similarly in both divalent ions.

\section{DISCUSSION}

Bulged RNA play a significant role in

bulge sequence changed the RNA stability in low-salt conditions, with a $\Delta \mathrm{G}_{37}^{\circ}$ of $-6.1 \mathrm{kcal} / \mathrm{mol}$ for CCC-TAR RNA and $\Delta \mathrm{G}^{\circ}{ }_{37}$ of $-3.8 \mathrm{kcal} / \mathrm{mol}$ for UCU-TAR RNA.

As RNA with different bulge sequences have different $\Delta \mathrm{G}^{\circ}{ }_{37}$ values in the absence of divalent ions, changes in RNA stability $\left(\Delta \Delta \mathrm{G}^{\circ}\right.$ relative to $0 \mathrm{mM}$ condition) were compared in various concentrations of $\mathrm{Ca}^{2+}$ (Fig. 2A) and $\mathrm{Mg}^{2+}$ (Fig. $2 \mathrm{~B}$ ) ions rather than the measured $\Delta \mathrm{G}^{\circ}{ }_{37}$ values. Interactions with $\mathrm{Mg}^{2+}$ or $\mathrm{Ca}^{2+}$ ions stabilized the cytosinerich bulged RNA by nearly $2-3 \mathrm{kcal} / \mathrm{mol}$ (Fig. 2, open rectangles represent CCU, filled circles represent CCC). The uracil-rich bulged RNA were stabilized by interactions with divalent ions: a $\Delta \Delta \mathrm{G}^{\circ} 37$ of $5.7 \mathrm{kcal} / \mathrm{mol}$ for UUU-TAR in $9.5 \mathrm{mM} \mathrm{Mg}^{2+}$ (Fig. 2B, filled triangles) and a $\Delta \Delta \mathrm{G}_{37}^{\circ}$ of $5.1 \mathrm{kcal} / \mathrm{mol}$ for UCU-TAR in $9.5 \mathrm{mM} \mathrm{Ca}^{2+}$ (Fig. 2A, filled diamonds). Interactions with $\mathrm{Mg}^{2+}$ ions were more favorable for the core helix than with $\mathrm{Ca}^{2+}$ (Fig. 2, open triangles).

\section{Contributions of monovalent and divalent ions to RNA stability}

RNA thermodynamic data are usually collected in $1 \mathrm{M}$ salt condition to obtain $\Delta \mathrm{G}^{\mathrm{o}}{ }_{37}$ values for RNA under conditions where charge-charge interactions are satisfied. Hence, a comparative analysis was performed between $\Delta \mathrm{G}^{\circ}{ }_{37}$ values obtained in $1 \mathrm{M} \mathrm{KCl}$ and in various concentrations of divalent ions $\left(\Delta \Delta \mathrm{G}^{\circ}\right.$ relative to $1 \mathrm{M} \mathrm{KCl}$ ) (Fig. 3). Based on the polyelectrolyte condensation theory (Bloomfield et al. 2000), TAR RNA in $9.5 \mathrm{mM}$ divalent ions is expected to be less stable than in $1 \mathrm{M}$ monovalent ions if the interactions between ions and RNA are purely electrostatic. Among the four bulge modifications examined here, only UCU-TAR RNA shows a 1.7 $\mathrm{kcal} / \mathrm{mol}$ gain in stability in $\mathrm{Ca}^{2+}$ (Fig. $3 \mathrm{~A}$, green bars); all other constructs show favorable interactions with $\mathrm{Mg}^{2+}$, with UUU-TAR interactions being the
TABLE 2. Thermodynamic parameters of TAR RNA in varying concentrations of calcium and magnesium ions ${ }^{\mathrm{a}}$

\begin{tabular}{|c|c|c|c|c|c|}
\hline & $\begin{array}{c}\Delta \mathrm{H}^{\circ} \\
(\mathrm{kcal} / \mathrm{mol})\end{array}$ & $\begin{array}{l}\Delta \mathrm{S}^{\circ} \\
(\mathrm{eu})\end{array}$ & $\begin{array}{c}\Delta \mathrm{G}^{\circ} \\
\left(\mathrm{kcal} / \mathrm{mol}, 37^{\circ} \mathrm{C}\right)\end{array}$ & $\begin{array}{c}T_{m} \\
\left({ }^{\circ} \mathrm{C}, 1.0 \mathrm{e}-04 \mathrm{M}\right)\end{array}$ & $\begin{array}{c}\Delta \Delta \mathrm{G}^{\circ} \\
\left(\mathrm{kcal} / \mathrm{mol}, 37^{\circ} \mathrm{C}\right)\end{array}$ \\
\hline \multicolumn{6}{|c|}{$\left[\mathrm{Ca}^{2+}\right] \mathrm{mM}$} \\
\hline 0 & $-63 \pm 3$ & $-190 \pm 12$ & $-3.8 \pm 0.2$ & 24.1 & 0 \\
\hline 0.5 & $-78 \pm 4$ & $-227 \pm 12$ & $-8.0 \pm 0.1$ & 42.8 & -4.2 \\
\hline 2.5 & $-89 \pm 4$ & $-259 \pm 12$ & $-8.7 \pm 0.1$ & 44.6 & -4.9 \\
\hline 9.5 & $-92 \pm 6$ & $-268 \pm 18$ & $-8.9 \pm 0.1$ & 45.2 & -5.1 \\
\hline \multicolumn{6}{|c|}{$\left[\mathrm{Mg}^{2+}\right] \mathrm{mM}$} \\
\hline 0.5 & $-64 \pm 5$ & $-186 \pm 15$ & $-6.2 \pm 0.2$ & 35.3 & -2.8 \\
\hline 2.5 & $-49 \pm 7$ & $-135 \pm 23$ & $-7.3 \pm 0.1$ & 41.7 & -3.9 \\
\hline 9.5 & $-60 \pm 4$ & $-166 \pm 14$ & $-8.2 \pm 0.2$ & 45.8 & -4.8 \\
\hline \multicolumn{6}{|c|}{$\left[\mathrm{Ba}^{2+}\right] \mathrm{mM}$} \\
\hline 0.5 & $-72 \pm 14$ & $-210 \pm 46$ & $-7.5 \pm 0.5$ & 41.3 & -3.7 \\
\hline 2.5 & $-61 \pm 8$ & $-171 \pm 24$ & $-8.6 \pm 0.2$ & 47.9 & -4.8 \\
\hline 9.5 & $-67 \pm 8$ & $-187 \pm 26$ & $-8.8 \pm 0.3$ & 48.3 & -5.0 \\
\hline
\end{tabular}

${ }^{\mathrm{a}} \Delta \Delta \mathrm{G}^{\circ}{ }_{37}$ were calculated by subtracting the $\Delta \mathrm{G}^{\circ}{ }_{37}$ measured at each concentration of divalent ions from the $0 \mathrm{mM}$ value. 
A

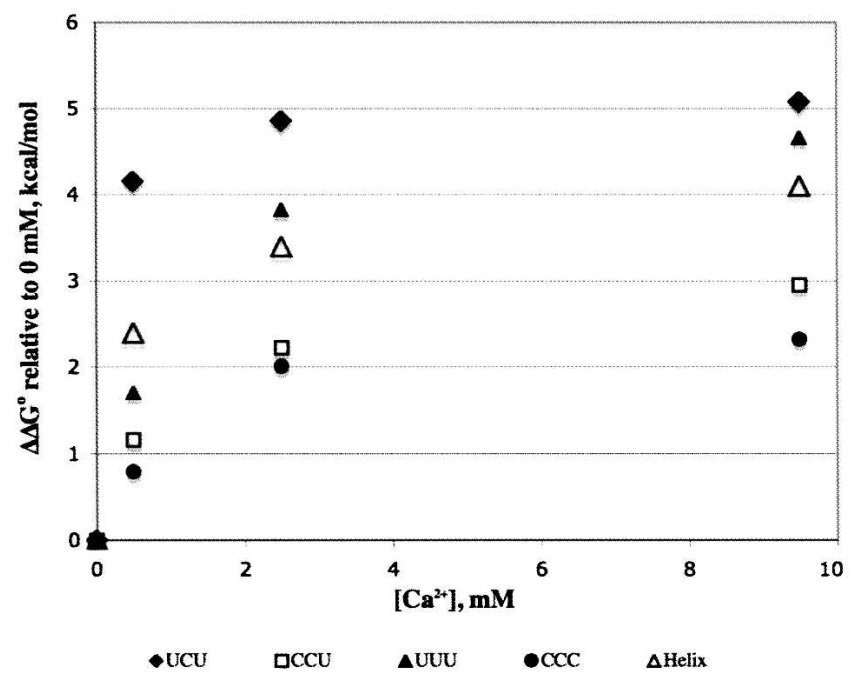

B

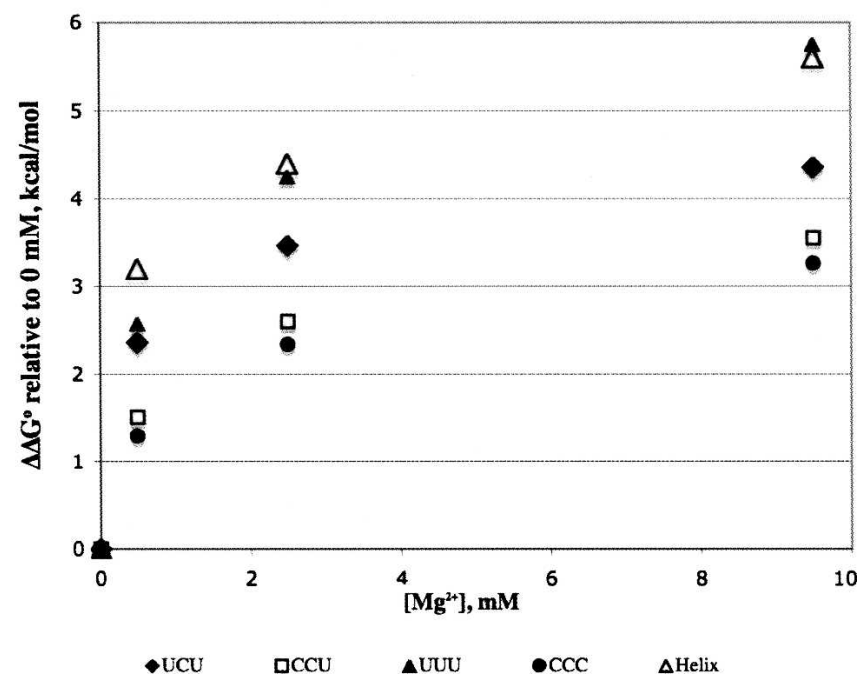

FIGURE 2. Plot of $\Delta \Delta \mathrm{G}^{\circ}{ }_{37}$ values in varying concentrations of calcium $(A)$ and magnesium ions $(B)$ relative to no divalent ion $(0 \mathrm{mM})$ buffer. The $\Delta \Delta \mathrm{G}_{37}^{\circ}$ values were calculated by subtracting the $\Delta \mathrm{G}^{\circ}{ }_{37}$ value in a given concentration of divalent ion from the value in $0 \mathrm{mM}$ buffer.

bulged RNA (Fig. 2; Tables 2, 4). In $1 \mathrm{M} \mathrm{KCl}$ (Table 1) and low-salt buffers (Tables 2, 4), cytosine-rich trinucleotidebulged RNAs were more stable. Addition of millimolar concentration of $\mathrm{Mg}^{2+}$ and $\mathrm{Ca}^{2+}$ ions increases stability for all RNA as expected (Figs. 2), but to varying degrees. In general, cytosine-rich bulge sequences gained $\sim 3 \mathrm{kcal} / \mathrm{mol}$, whereas uracil-rich bulge sequences gained $\sim 5 \mathrm{kcal} / \mathrm{mol}$ in stability upon interactions with divalent ions (over the lowsalt conditions). The average stability of pyrimidine-containing bulged RNA was $-8.6 \mathrm{kcal} / \mathrm{mol}$ in $9.5 \mathrm{mM} \mathrm{Ca}^{2+}$ and $-9.1 \mathrm{kcal} / \mathrm{mol}$ in $9.5 \mathrm{mM} \mathrm{Mg}{ }^{2+}$. The ability of bulged nucleotides to interact with each other and with the neighboring base pairs can effect the local electrostatic environment, hydration, conformations, and ion binding (Auffinger and Westhof 2000; Draper 2004); all of these differences are reflected in the measured $\Delta G^{\circ}{ }_{37}$ values reported here. In the case of TAR RNA, various conformations have indeed been seen under various ionic conditions (Aboul-ela et al. 1995, 1996; Edwards and Sigurdsson 2003; Pitt et al. 2004; Casiano-Negroni et al. 2007; Zhang et al. 2007).

As shown in Figure 3, changing U23 to $\mathrm{C} 23$ significantly alters the $\mathrm{Ca}^{2+}$ interactions but does not alter $\mathrm{Mg}^{2+}$ interactions. Changing C24 to U24 significantly alters both the $\mathrm{Ca}^{2+}$ and $\mathrm{Mg}^{2+}$ interactions. Changing both uracil 23 and 25 to cytosine primarily alters the $\mathrm{Ca}^{2+}$ interactions and not $\mathrm{Mg}^{2+}$ interactions. These results suggest that divalent interactions with U23 and C24 are sufficiently different to lead to measurable differences in $\Delta \mathrm{G}^{\mathrm{o}}{ }_{37}$ values. NMR data from Al-Hashimi and coworkers showed differences in interactions for $\mathrm{U} 23$ between $\mathrm{Na}^{+}$ and $\mathrm{Mg}^{2+}$ ions (Pitt et al. 2004; Casiano-Negroni et al. 2007). EPR data from Sigurdsson and coworkers showed $\mathrm{Na}^{+}$and $\mathrm{Ca}^{2+}$ interactions were similar and influence U23; $\mathrm{Mg}^{2+}$ additionally influences mobility at position U25 (EPR data was not collected for cytosine in the bulge) (Edwards and Sigurdsson 2003). Thermodynamic analyses presented here suggest that both U23 and C24 play a role in divalent ion interactions and could potentially play a role in allowing bulged RNA to sample various stable conformations. Our results show that single nucleotide substitution or modification can lead to differences in divalent ion interactions. Thus, single-base substitution or base-modification experiments should be interpreted with caution in identifying metal ion binding sites, especially when these sites involve nonhelical, dynamic regions in RNA structure.

TABLE 3. Thermodynamics parameters of UCU-TAR RNA in $100 \mathrm{mM} \mathrm{K}^{+}$buffer conditions ${ }^{\mathrm{a}}$

\begin{tabular}{lccccc}
\hline $\begin{array}{l}\text { llons] } \\
\mathrm{mM}\end{array}$ & $\begin{array}{c}\Delta \mathrm{H}^{\circ} \\
(\mathrm{kcal} / \mathrm{mol})\end{array}$ & $\begin{array}{c}\Delta \mathrm{S}^{\circ} \\
(\mathrm{eu})\end{array}$ & $\begin{array}{c}\Delta \mathrm{G}^{\circ} \\
(\mathrm{kcal} / \mathrm{mol}, \\
\left.37^{\circ} \mathrm{C}\right)\end{array}$ & $\begin{array}{c}T_{m}\left({ }^{\circ} \mathrm{C},\right. \\
1.0 \mathrm{e}-04 \mathrm{M})\end{array}$ & $\begin{array}{c}\Delta \Delta \mathrm{G}^{\text {ob }} \\
(\mathrm{kcal} / \mathrm{mol}, \\
\left.37^{\circ} \mathrm{C}\right)\end{array}$ \\
\hline $100 \mathrm{mM} \mathrm{K}^{+}$ & $-62 \pm 4$ & $-176 \pm 12$ & $-6.6 \pm 0.1$ & 36.7 & 0 \\
$0.5 \mathrm{mM} \mathrm{Ca}^{2+}$ & $-91 \pm 8$ & $-270 \pm 26$ & $-7.6 \pm 0.2$ & 40.7 & 1.0 \\
$9.5 \mathrm{mM} \mathrm{Ca}^{2+}$ & $-88 \pm 4$ & $-254 \pm 12$ & $-8.7 \pm 0.1$ & 44.9 & 2.1 \\
$0.5 \mathrm{mM} \mathrm{Mg}^{2+}$ & $-64 \pm 4$ & $-185 \pm 13$ & $-6.8 \pm 0.1$ & 38.1 & 0.2 \\
$9.5 \mathrm{mM} \mathrm{Mg}^{2+}$ & $-61 \pm 4$ & $-172 \pm 12$ & $-7.3 \pm 0.1$ & 41.2 & 0.7 \\
\hline
\end{tabular}

${ }^{\mathrm{a}} \Delta \Delta \mathrm{G}^{\circ}{ }_{37}$ were calculated by subtracting the $\Delta \mathrm{G}^{\circ}{ }_{37}$ measured at each concentration of divalent ions from the $100 \mathrm{mM} \mathrm{K}^{+}$value. 
TABLE 4. Thermodynamic parameters of modified bulged TAR RNA in varying concentrations of calcium and magnesium ions

\begin{tabular}{|c|c|c|c|c|}
\hline & $\begin{array}{c}\Delta \mathrm{H}^{\circ} \\
(\mathrm{kcal} / \mathrm{mol})\end{array}$ & $\begin{array}{l}\Delta \mathrm{S}^{\circ} \\
(\mathrm{eu})\end{array}$ & $\begin{array}{c}\Delta \mathrm{G}^{\circ} \\
\left(\mathrm{kcal} / \mathrm{mol}, 37^{\circ} \mathrm{C}\right)\end{array}$ & $\begin{array}{c}T_{m} \\
\left({ }^{\circ} \mathrm{C}, 1.0 \mathrm{e}-04 \mathrm{M}\right)\end{array}$ \\
\hline \multicolumn{5}{|l|}{$\underset{\left[\mathrm{Ca}^{2+}\right]}{\mathrm{CCU}}$} \\
\hline 0 & $-52 \pm 4$ & $-150 \pm 13$ & $-5.4 \pm 0.2$ & 30.4 \\
\hline 0.5 & $-59 \pm 3$ & $-170 \pm 10$ & $-6.6 \pm 0.1$ & 37.2 \\
\hline 2.5 & $-61 \pm 4$ & $-173 \pm 13$ & $-7.6 \pm 0.1$ & 42.7 \\
\hline 9.5 & $-63 \pm 4$ & $-177 \pm 14$ & $-8.4 \pm 0.1$ & 46.2 \\
\hline \multicolumn{5}{|c|}{$\left[\mathrm{Mg}^{2+}\right] \mathrm{mM}$} \\
\hline 0.5 & $-59 \pm 3$ & $-168 \pm 11$ & $-6.9 \pm 0.1$ & 39.0 \\
\hline 2.5 & $-66 \pm 4$ & $-186 \pm 12$ & $-8.0 \pm 0.1$ & 44.1 \\
\hline 9.5 & $-69 \pm 3$ & $-193 \pm 8$ & $-9.0 \pm 0.1$ & 48.3 \\
\hline \multicolumn{5}{|c|}{$\begin{array}{l}\text { UUU } \\
\qquad\left[\mathrm{Ca}^{2+}\right] \mathrm{mM}\end{array}$} \\
\hline 0 & $-61 \pm 2$ & $-184 \pm 6$ & $-4.0 \pm 0.1$ & 24.5 \\
\hline 0.5 & $-75 \pm 3$ & $-224 \pm 9$ & $-5.7 \pm 0.1$ & 33.5 \\
\hline 2.5 & $-85 \pm 9$ & $-247 \pm 29$ & $-7.8 \pm 0.2$ & 41.7 \\
\hline 9.5 & $-77 \pm 4$ & $-220 \pm 12$ & $-8.6 \pm 0.1$ & 45.7 \\
\hline \multicolumn{5}{|c|}{$\left[\mathrm{Mg}^{2+}\right] \mathrm{mM}$} \\
\hline 0.5 & $-75 \pm 9$ & $-221 \pm 30$ & $-6.5 \pm 0.3$ & 37.0 \\
\hline 2.5 & $-82 \pm 10$ & $-238 \pm 31$ & $-8.2 \pm 0.3$ & 43.5 \\
\hline 9.5 & $-94 \pm 6$ & $-270 \pm 18$ & $-9.7 \pm 0.1$ & 47.9 \\
\hline \multicolumn{5}{|c|}{$\mathrm{CCC}$} \\
\hline \multicolumn{5}{|c|}{$\left[\mathrm{Ca}^{2+}\right] \mathrm{mM}$} \\
\hline 0 & $-60 \pm 5$ & $-171 \pm 17$ & $-6.1 \pm 0.2$ & 34.6 \\
\hline 0.5 & $-62 \pm 5$ & $-177 \pm 15$ & $-6.9 \pm 0.1$ & 38.7 \\
\hline 2.5 & $-74 \pm 7$ & $-213 \pm 21$ & $-8.1 \pm 0.2$ & 43.6 \\
\hline \multicolumn{5}{|c|}{$\left[\mathrm{Mg}^{2+}\right] \mathrm{mM}$} \\
\hline 0.5 & $-68 \pm 4$ & $-197 \pm 14$ & $-7.4 \pm 0.1$ & 40.8 \\
\hline 2.5 & $-77 \pm 4$ & $-220 \pm 12$ & $-8.4 \pm 0.1$ & 44.8 \\
\hline 9.5 & $-73 \pm 3$ & $-204 \pm 11$ & $-9.3 \pm 0.1$ & 49.5 \\
\hline \multicolumn{5}{|c|}{$\begin{array}{l}\text { Core helix } \\
{\left[\mathrm{Ca}^{2+}\right] \mathrm{mM}}\end{array}$} \\
\hline 0 & $-83 \pm 3$ & $-234 \pm 8$ & $-10.7 \pm 0.1$ & 53.2 \\
\hline 0.5 & $-87 \pm 3$ & $-237 \pm 10$ & $-13.1 \pm 0.2$ & 62.4 \\
\hline 2.5 & $-89 \pm 4$ & $-235 \pm 13$ & $-14.1 \pm 0.2$ & 66.5 \\
\hline $\begin{array}{c}9.5 \\
{\left[\mathrm{Mg}^{2+}\right]}\end{array}$ & $-90 \pm 4$ & $-243 \pm 13$ & $-14.8 \pm 0.2$ & 68.6 \\
\hline 0.5 & $-82 \pm 6$ & $-220 \pm 16$ & $-13.9 \pm 0.4$ & 67.5 \\
\hline 2.5 & $-92 \pm 3$ & $-248 \pm 7$ & $-15.1 \pm 0.2$ & 68.8 \\
\hline 9.5 & $-98 \pm 3$ & $-262 \pm 10$ & $-16.3 \pm 0.3$ & 71.6 \\
\hline
\end{tabular}

\section{MATERIALS AND METHODS}

\section{RNA design and purification}

To study the stability of trinucleotide bulge sequences and their interactions with metal ions, a TAR-RNA construct (UCU-TAR, WT TAR) (Fig. 1) containing the $\mathrm{U}_{23} \mathrm{C}_{24} \mathrm{U}_{25}$ bulge (numbering system of HIV-1 TAR RNA) and the two conserved base pairs on each helical stem was designed. To understand the effect of the UCU sequence on TAR RNA stability and its interactions with divalent ions, single modifications in pyrimidine sequence in the bulge region were designed by changing one bulge nucleotide at a time-U23 to C23 modification (CCUTAR) and C24 to U24 (UUU-TAR). One construct containing a double modification, $\mathrm{U} 23$ to $\mathrm{C} 23$ and $\mathrm{U} 25$ to C25 (CCC-TAR), was also designed to study any combined effect of positions 23 and 25 on RNA stability and ion interactions. A core helix sequence,

$$
\begin{gathered}
{ }^{5^{\prime}} \text { GAGAGACGA }{ }^{3^{\prime}} \\
{ }^{\prime} \text { ACUCUCUGC } \\
5^{\prime},
\end{gathered}
$$

was designed by eliminating the bulge sequence (RNA designed by base pairing the bulge sequence forms a structure that is too stable for these experiments.)

All RNA constructs were designed to be non-self-complementary and were ordered from Dharmacon, Inc. A hairpin RNA was not used for several reasons: the loop region is expected to interact with divalent ions, most bulges are present in helices, base substitution experiments are easier and cheaper to design in a duplex RNA, and data analysis for duplexes is more robust. RNA were purified with a thin-layer chromatography using $20 \mathrm{~cm} \times 20 \mathrm{~cm}, 500-\mathrm{mm}$ thick silica plates with a running buffer of 6:3:1 (v/v/v) 1-propanol, 30\% ammonium hydroxide, and water. The samples were spin filtered to remove any excess silica and dried using SPD1010 SpeedVac System (Savant); samples were deprotected in a

A simple thermodynamic profile of the native and modified RNA (under experimentally relevant conditions) may serve as a diagnostic for changes in RNA structure.

In this study we show that bulged RNA have varying stability in both low salt and $1 \mathrm{M} \mathrm{KCl}$ condition, and their interactions with divalent ions can be quantified. Inclusion of the divalent ion interactions of RNA under biochemically relevant conditions is likely to improve RNA secondary structure prediction and in vitro experimental design, especially as large RNA contain multiple ion interaction sites.
$100-\mathrm{mM}$ acetic acid buffer adjusted to $\mathrm{pH} 3.8$ with TEMED. The samples were desalted using C18 Sep-Pak column (Waters). The loading buffer was $5 \mathrm{mM}$ sodium bicarbonate at $\mathrm{pH}$. Elution was performed twice using $2 \mathrm{~mL}$ of $30 \%$ acetonitrile, and once using 2 $\mathrm{mL}$ of $100 \%$ acetonitrile. The fractions containing RNA were dried. The concentrations of RNA were determined using extinction coefficient derived from pairwise values for nearest neighbors.

\section{Thermal denaturation experiments and data analysis}

All thermodynamic data were collected on a Cary 100 Bio UVVisible Spectrophotometer fitted with $6 \times 6$ Peltier unit. Buffer 
A

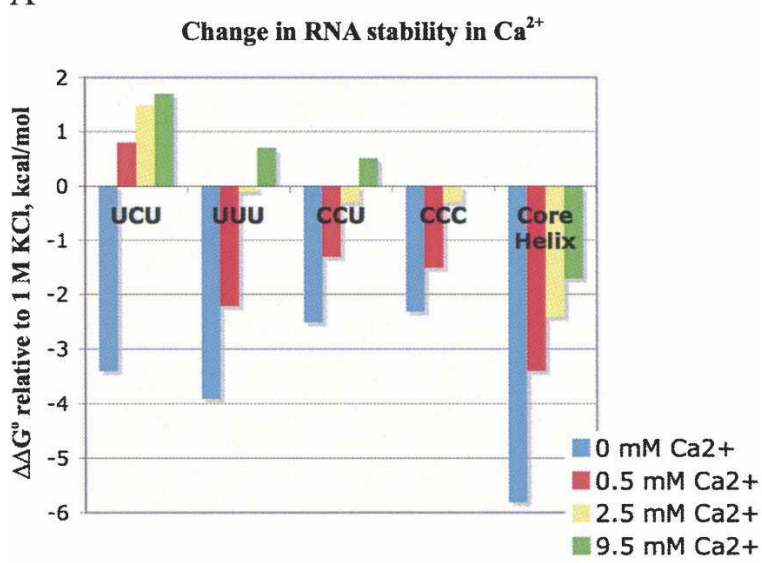

B

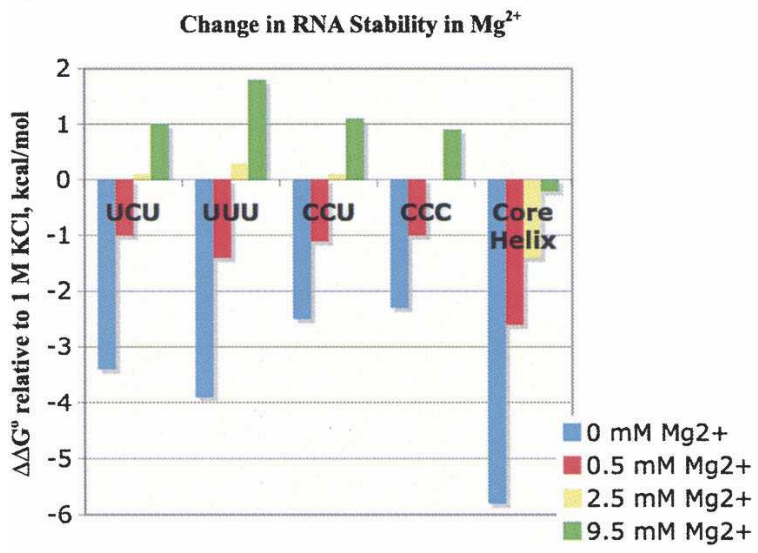

FIGURE 3. Plot of $\Delta \Delta \mathrm{G}^{\circ}{ }_{37}$ values relative to $1 \mathrm{M} \mathrm{K}^{+}$ions. The $\Delta \Delta \mathrm{G}^{\circ}{ }_{37}$ values were calculated by taking the difference in the $\Delta \mathrm{G}^{\circ}{ }_{37}$ in a given concentration of calcium $(A)$ or magnesium ions $(B)$ and $1 \mathrm{M}$ $\mathrm{KCl}$. The positive $\Delta \Delta \mathrm{G}^{\circ}{ }_{37}$ value indicates that the RNA is more stable in divalent ions relative to $1 \mathrm{M} \mathrm{KCl}$.

conditions used were similar to those used for biochemical experiments. Samples were prepared with equimolar amounts of each RNA strand. All samples were run in a buffer containing $10 \mathrm{mM}$ cacodylic acid, $10 \mathrm{mM} \mathrm{KCl}$, and $0.5 \mathrm{mM}$ EDTA at $\mathrm{pH} 6(0$ $\mathrm{mM}$ buffer). For divalent metal ion titration experiments, appropriate amounts of calcium chloride or magnesium chloride were added to the $0 \mathrm{mM}$ buffer. The concentrations of divalent ions were established by complexometric titrations or atomic absorption spectroscopy (with the detection limit in low- to submicromolar range, respectively). The buffers were labeled based on the net concentration of divalent ions. For example, $10 \mathrm{mM}$ cacodylic acid, $10 \mathrm{mM} \mathrm{KCl,} 0.5 \mathrm{mM}$ EDTA, and $10 \mathrm{mM} \mathrm{CaCl}_{2}$ buffer was labeled as $9.5 \mathrm{mM} \mathrm{Ca}^{2+}$ buffer. Stability of the UCU-TAR RNA was also measured in buffer containing various concentrations of $\mathrm{BaCl}_{2}$. Thermodynamic parameters for each construct were also measured in $1 \mathrm{M} \mathrm{KCl}$ (added to the $0 \mathrm{mM}$ buffer), as it provides a reference for maximum stability in the absence of divalent-specific interactions. A few samples of TAR RNA were tested for their interactions with divalent metal-RNA interactions in a buffer containing $100 \mathrm{mM} \mathrm{K}^{+}$. Thermodynamic data were collected using a nine-step dilution scheme to generate an $\sim 50$-fold concentration range for thermal denaturation experiments. The change in RNA absorbance was monitored at a wavelength of $280 \mathrm{~nm}$.

The melt curves generated by thermal denaturation experiments were analyzed using the two-state model (Xia et al. 1998; Matthews et al. 2004). Linear sloping baselines and temperatureindependent enthalpy and entropy values were assumed to generate thermodynamic parameters using the Meltwin program to fit individual melt curves (McDowell and Turner 1996). Thermodynamic parameters generated by individual curve fit were compared with those generated by $T_{m}^{-1}$ versus $\log \left(C_{T} / 4\right)$ plot for non-self-complementary RNA using equations 1 and 2 (where, $T_{m}$ is the melting temperature, $C_{T}$ is the total concentration of RNA, and $R$ is the gas constant).

$$
T_{m}^{-1}=2.303\left(\frac{R}{\Delta \mathrm{H}^{o}}\right) \log \left(\frac{C_{T}}{4}\right)+\left(\frac{\Delta \mathrm{S}^{o}}{\Delta \mathrm{H}^{o}}\right),
$$

$$
\Delta \mathrm{G}^{\circ}=\Delta \mathrm{H}^{\circ}-T \Delta \mathrm{S}^{\circ}
$$

Thermodynamic data reported is from the van't Hoff analysis $\left[T_{m}^{-1}\right.$ versus $\log \left(C_{T} / 4\right)$ plots $]$.

\section{ACKNOWLEDGMENTS}

This work was funded through a National Science Foundation Grant, MCB-0621509 (N.G.), Venture Grants, and through divisional and college-wide funding. NSF-REU grant CHE 024412 (PI Dr. Krugh) funded I.C.-O. research in the Turner laboratory. I.C.-O. and D.B. were both funded by the Boettcher Foundation of Colorado for their undergraduate education at the Colorado College. We are grateful to Dr. Douglas Turner for providing an intellectually stimulating environment for N.G.'s sabbatical and I.C.-O.'s summer research. We thank Dr. Harold Jones for editorial assistance and the Department of Chemistry and Biochemistry at the Colorado College for prioritizing undergraduate research.

Received July 16, 2008; accepted September 3, 2008.

\section{REFERENCES}

Aboul-ela, F., Karn, J., and Varani, G. 1995. The structure of the human immunodeficiency virus type-I TAR RNA reveals principles of RNA recognition by Tat protein. J. Mol. Biol. 253: 313-332.

Aboul-ela, F., Karn, J., and Varani, G. 1996. Structure of HIV-1 TAR RNA in the absence of ligands reveals a novel conformation of the trinucleotide bulge. Nucleic Acids Res. 24: 3974-3981.

Auffinger, P. and Westhof, E. 2000. Water and ion binding around RNA and DNA (C,G) oligomers. J. Mol. Biol. 300: 1113-1131.

Basu, S., Rambo, R.P., Strauss-Soukup, J., Cate, J.H., FerréD'Amaré, A.R., Strobel, S.A., and Doudna, J.A. 1998. A specific monovalent metal ion integral to the AA platform of the RNA tetraloop receptor. Nat. Struct. Biol. 5: 986-992.

Bloomfield, V.A., Crothers, D.M., and Tinoco, I. 2000. Nucleic acids: Structure, properties, and function, Chap. 11. In University Science Books, Sausalito, CA.

Calnan, B.J., Tidor, B., Biancalana, S., Hudson, D., and Frankel, A.D. 1991. Arginine-mediated RNA recognition: The arginine fork. Science 252: 1167-1171. 
Casiano-Negroni, A., Sun, X., and Al-Hashimi, H.M. 2007. Probing $\mathrm{Na}^{+}$-induced changes in the HIV-1 TAR conformational dynamics using NMR residual dipolar couplings: New insights into the role of counterions and electrostatic interactions in adaptive recognition. Biochemistry 46: 6525-6535.

Cate, J.H. and Doudna, J.A. 1996. Metal-binding sites in the major groove of a large ribozyme domain. Structure 4: 1221-1229.

Coffin, J.M., Hughes, S.H., and Varmus, H.E 1997. Retroviruses. Cold Spring Harbor Laboratory Press, Cold Spring Harbor, NY.

Cordingley, M.J., LaFemina, R.L., Callahan, P.L., Condra, J.H., Sardana, V.V., Graham, D.J., Nguyen, T.M., LeGrow, K., Gotlib, L., Schlabach, A., et al. 1990. Sequence specific interaction of Tat protein and Tat peptides with the transactivation-responsive sequence element of human immunodeficiency virus type 1 in vitro. Proc. Natl. Acad. Sci. 87: 8985-8989.

Correll, C.C., Freeborn, B., Moore, P.B., and Steitz, T.A. 1997. Metals, motifs, and recognition in the crystal structure of a 5S rRNA domain. Cell 91: 705-712.

Dingwall, C., Ernberg, I., Gait, M.J., Green, S.M., Heapy, S., Karn, J., Lowe, A.D., Singh, M., Skinner, M.A., and Valerio, R. 1989. Human immunodeficiency virus 1 Tat protein binds transactivation-responsive region (TAR) RNA in vitro. Proc. Natl. Acad. Sci. 86: 6925-6929.

Draper, D.E. 2004. A guide to ions and RNA structure. RNA 10: 335-343.

Edwards, T.E. and Sigurdsson, S.T. 2003. EPR spectroscopic analysis of TAR RNA-metal interactions. Biochem. Biophys. Res. Commun. 303: 721-725.

Frankel, A.D. and Young, J.A.T. 1998. HIV-1: Fifteen proteins and an RNA. Annu. Rev. Biochem. 67: 1-25.

Hermann, T. and Patel, D.J. 2000. RNA bulges as architectural and recognition motifs. Structure 8: R47-R54.

Huesken, D., Goodall, G., Blommers, M.J.J., Jahnke, W., Hall, J., Haener, R., and Moser, H.E. 1996. Creating RNA bulges: Cleavage of RNA in RNA/DNA duplexes by metal ion catalysis. Biochemistry 35: 16591-16600.

Ippolito, J.A. and Steitz, T.A. 1998. A $1.3 \AA$ resolution crystal structure of the HIV-1 trans-activation response region RNA stem reveals a metal ion-dependent bulge conformation. Proc. Natl. Acad. Sci. 95: 9819-9824.

Madder, A., Ehrl, R., and Stroemberg, R. 2003. Stabilization of RNA bulges by oligonucleotide complements containing an adenosine analogue. ChemBioChem 4: 1194-1200.

Matthews, D.H., Disney, M., Childs, J., Schroeder, S., Zuker, M., and Turner, D.H. 2004. Incorporating chemical modification constraints into a dynamic programming algorithm for prediction of RNA secondary structure. Proc. Natl. Acad. Sci. 101: 7287-7292.
McDowell, J.A. and Turner, D.H. 1996. Investigation of the structural basis for thermodynamic stabilities of tandem GU mismatches: Solution structure of (rGAGGUCUC) ${ }_{2}$ by two-dimensional NMR and simulated annealing. Biochemistry 35: 14077-14089.

Muesing, M.A., Smith, D.H., and Capon, D.J. 1987. Regulation of mRNA accumulation by a human immunodeficiency virus transactivator protein. Cell 48: 691-701.

Musselman, C., Al-Hashimi, H.M., and Andricioaei, I. 2007. iRED analysis of TAR RNA reveals motional coupling, long-range correlations, and a dynamical hinge. Biophys. J. 93: 411-422.

Pitt, S.W., Majumdar, A., Serganov, A., Patel, D.J., and AlHashimi, H.M. 2004. Argininamide binding arrests global motions in HIV-1 TAR RNA: Comparison with $\mathrm{Mg}^{2+}$-induced conformational stabilization. J. Mol. Biol. 338: 7-16.

Puglisi, J.D., Tan, R., Calnan, B.J., Frankel, A.D., and Williamson, J.R. 1992. Conformation of the TAR RNA-arginine complex by NMR spectroscopy. Science 257: 76-80.

Roy, S., Delling, U., and Chen, C.H. 1990. A bulge structure in HIV-1 TAR RNA is required for Tat binding and Tat mediated transactivation. Genes \& Dev. 4: 1365-1373.

Tao, J. and Frankel, A.D. 1992. Specific binding of arginine to TAR RNA. Proc. Natl. Acad. Sci. 89: 2723-2726.

Turner, D.H. 1992. Bulges in nucleic acids. Curr. Opin. Struct. Biol. 2: 334-337.

Weeks, K.M., Ampe, C., Schultz, S.C., Steitz, T.A., and Crothers, D.M. 1990. Fragments of the HIV-1 Tat protein specifically bind TAR RNA. Science 249: 1281-1285.

White, S.A. and Draper, D.E. 1987. Single base bulges in small RNA hairpins can enhance intercalation of ethidium. Nucleic Acids Res. 15: 4049-4064.

$\mathrm{Wu}, \mathrm{H} .-\mathrm{N}$. and Uhlenbeck, O.C. 1987. Role of a bulged A residue in a specific RNA protein interaction. Biochemistry 26: 8221-8227.

Xia, T.B., SantaLucia, J., Bruckard, M.E., Kierzek, R., Schroeder, S.J., Zuker, M., and Turner, D.H. 1998. Thermodynamic parameters for an expanded nearest-neighbor model for formation of RNA duplexes with Watson-Crick base pairs. Biochemistry 37: 14719-14735.

Zacharias, M. and Hagerman, P.J. 1995a. The bend in RNA created by the trans-activation response element bulge of human immunodeficiency virus is straightened by arginine and by Tat-derived peptide. Proc. Natl. Acad. Sci. 92: 6052-6056.

Zacharias, M. and Hagerman, P.J. 1995b. Bulge-induced bends in RNA; quantification by transient electric birefringence. J. Mol. Biol. 247: 486-500.

Zhang, Q., Stelzer, A.C., Fisher, C.K., and Al-Hashimi, H.M. 2007. Visualizing spatially correlated dynamics that directs RNA conformational transitions. Nature 450: 1263-1267. 

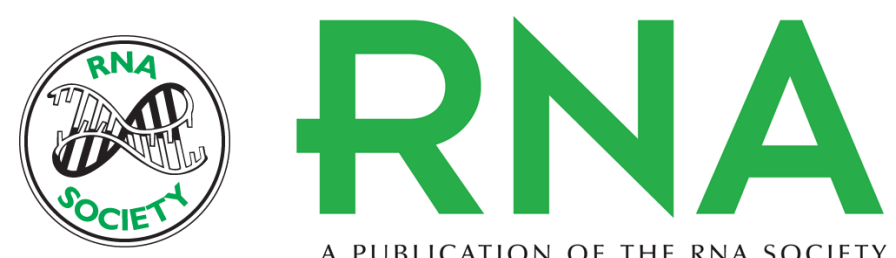

A PUBLICATION OF THE RNA SOCIETY

\section{Thermodynamic examination of trinucleotide bulged RNA in the context of HIV-1 TAR RNA}

Ian Carter-O'Connell, David Booth, Bryan Eason, et al.

RNA 2008 14: 2550-2556 originally published online October 24, 2008

Access the most recent version at doi:10.1261/rna.1004108

References This article cites 33 articles, 11 of which can be accessed free at:

http://rnajournal.cshlp.org/content/14/12/2550.full.html\#ref-list-1

License

Email Alerting Receive free email alerts when new articles cite this article - sign up in the box at the Service top right corner of the article or click here.

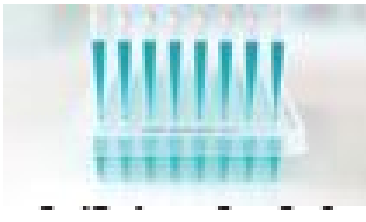

Providing Precise Solutions for your research.

To subscribe to RNA go to:

http://rnajournal.cshlp.org/subscriptions 